\title{
Zero Budget Natural Farming in India- A Review
}

\author{
Davinder Pal Singh Badwal', Mandeep Kumar ${ }^{2 *}$, Harjinder Singh ${ }^{3}$, \\ Simran $^{1}$ and Sandeep Kaur ${ }^{1}$
}

${ }^{1}$ Department of Agriculture Sciences, Sant Baba Bhag Singh University, Khiala, Jalandhar, Punjab, India

${ }^{2}$ Department of Genetics and Plant Breeding, Lovely Professional University, Phagwara, Punjab, India

${ }^{3}$ Department of Agriculture, Government College, Hoshiarpur, Punjab, India

*Corresponding author

\section{A B S T R A C T}

Keywords

Zero budget,

Farming,

Conventional,

Pesticides and

fertilizers

Article Info

Accepted:

10 November 2019

Available Online:

10 December 2019
Using conventional techniques in agriculture is not good for our soil and health as well. It makes soil barren as well as farmer goes under debt. Hence, the only approach to deal with this ever rising problem is zero budget natural farming (ZBNF). The word 'budget' refers to credit and expenses, thus the phrase 'zero budget' means without using any credit and without spending any money on purchased inputs. 'Natural farming' means farming without using the chemicals. Subhash Palekar, the explorer of ZBNF, introduces many principles and methods of ZBNF. Zero Budget Farmers use natural pesticides and fertilizers. The principal methods of ZBNF include crop rotation, green manures and compost, biological pest control. There are 4 pillars of ZBNF i.e. Jivamrita, Bijamrita, Acchhadana and Whappasa.

\section{Introduction}

The neoliberalization of the Indian economy led to a deep agrarian crisis that is making small scale farming an unviable vocation. Privatized seeds, inputs, and markets are inaccessible and expensive for peasants. Indian farmers increasingly find themselves in a vicious cycle of debt, because of the high production costs, high interest rate of credit, the volatile market price of crops, the rising costs of fuel based inputs and private seeds. More than a quarter of million farmers have committed suicides due to debt. It is a problem for farmers across India. This creates a serious problem in the Agriculture industry. The continuous use of pesticides and chemicals has severe effects on human health. After 
witnessing the harmful effects of chemical farming, newly introduced agriculture technique among farmers is zero budget natural farming (ZBNF), also known as zero budget spiritual farming (ZBSF). It has attained wide success in southern India especially Karnataka where it was firstly evolved (Kumar, 2012). Now it is spreading all over India, so rapidly.

ZBNF is a method of farming where the cost of growing and harvesting the plants is zero. 'Zero Budgets' farming promises to end a reliance on loans and cut production costs, ending the debt cycle for desperate farmers. The word 'Budget' refers to credit and expenses, thus the phrase 'Zero Budget' means without using any credit, and without spending any money on purchased inputs and without chemicals.

This method of farming was introduced by Shri Subhash Palekar, for which he was honored with Padma Shri in 2016 (Anonymous, 2016).

The movement in Karnataka state was born out of collaboration between Subash Palekar, who put together the ZBNF practices, and the state farmer association Karnataka Rajya Raitha Sangha (KRRS), member of La via Campesina (LVC) (Campesina, 2016). Many members of KRRS are also members of ZBNF movement, which is a broader entity and includes many other farmers. Still, KRRS was instrumental in mobilizing farmers at the grassroots level and organized many massive ZBNF training camps with the help of other allies. One might say that the organizational fabric of KRRS was like the culture medium upon which the ZBNF movement grew. These are the key activities organized by the ZBNF movement at the state level. ZBNF extends well beyond KRRS and include many other allies and members, but KRRS is a key ally at the state level.

\section{What is zero budget natural farming}

The basic "toolkit" of ZBNF methods was put together by Palekar. He is from a small village Amravati, Maharashtra, India. He is very much dedicated towards the betterment of his village farm, he experimented and revealed that the continuous use of chemicals effect the soil fertility and made the field barren (Jannoura et al., 2014).

In 1966-88 Palekar researched on forest vegetation. After huge efforts in field work, he introduced new method of farming as ZBNF. After six years of dedicated research, Palekar revealed that the dung of local Indian cows is effective in re-enrichment of barren soil, Dung and urine of black coloured Kapila cow is believed to be phenomenal. To get most out of cow dung and urine, ensure that dung is as fresh as possible and that the urine is as stale as possible (Pawar et al., 2013). Urine, jiggery and dicot flour can be used as additives.

The lesser milk the cow gives, the more beneficial its dung towards the reviving of soil (Babu, 2008). An acre of land requires $10 \mathrm{~kg}$ of cow dung per month. Since the average cow gives $11 \mathrm{~kg}$ of dung a day, dung from one cow can help fertilize 30 acres of land per month. "ZBNF is self-nourishing and symbiotic in nature" (Palekar, 2014). Privatized seeds, inputs and markets are difficult to get to and expensive for farmers.

Indian farmers increasingly found themselves under debt, because of high production costs. Under such conditions, ZBNF promises to end a reliance on loans and drastically cuts production costs, ending the debt cycle for desperate farmers (Mural, 2016). Palekar has published a series of books-more than 60 in various Indian languages such as, the philosophy of spiritual faming, five layer palekar Models etc, where he explains the ZBNF practices in great detail. 
Zero budget natural farming (ZBNF) has basically four pillars Jivamrita, Bijamrita, Acchadana-Mulching, Whapsa moisture (Palekar, 2014) which are mentioned in Table 1. Other important principles are intercropping, contour and bund system, local species of earthworm. Palekar also gave formulae for pest management, Agniastra, Brahmastra, Neemastra which is mentioned in Table 2. Panwar et al., (2013) reported that the application of FYM 5 t/ha + Vermicompost $2.5 \mathrm{t} / \mathrm{ha}+$ Jeevamrita 2 times (30 and 45 DAS) to Kharif sweet corn recorded significantly higher values for sweet corn cob and green fodder yield. Jannoura et al., (2014) revealed that organic fertilizer application improved nodule dry weight, photosynthetic rates, Nitrogen fixation as well as $\mathrm{N}$ concentration in several crops. Ramesh and Rao (2009) also reported that soil health could be sustained with organic nutrition due to soil diversification of soil biota. Rao et al., (2013) observed that the dynamics of various soil fertility parameters i.e. soil organic carbon, available phosphorous, available potassium, all of them were found built up to considerable extent with use of organic manures to maize and sunflower.

Khadse et al., (2017) survey 97 farmers who are practicing $\mathrm{ZBNF}$ and the reasons for adoption of ZBNF is family health (54\%), environmental reasons( $42 \%)$, reduce of cost of production $(38 \%)$, reduce debt $(30 \%)$ and many other reasons. The pest attack reduced up to $84 \%$, production costs decreased up to $91 \%$ and need of credit decreased up to $93 \%$.

The Government of Andhra Pradesh (GOAP) has invited Palekar to organize training camps of ZBNF in January 2016 and September 2016. In 2016-17, 48565 farmers have been covered as a target for practice of ZBNF. GOAP, 2017 reported that Yield of Paddy is increased as $6416 \mathrm{~kg} / \mathrm{ha}$ in ZBNF as compared to $5816 \mathrm{~kg} / \mathrm{ha}$ in Non-ZBNF and Cost Reduction is reduced up to $5000-15000$, so Net Additional Income by ZBNF in paddy is up to $14000-25000 \mathrm{~kg} / \mathrm{ha}$.

The benefits of ZBNF are little/no cost, zero chemical usage, use local seeds, less water requirement, zero budgets facilitate income throughout the year and reduces risk. It has also been mentioned here that ZBNF exemplifies agro ecology. A survey carried out by LVC suggests that ZBNF works not just in agronomic terms, but also brings about a variety of social and economical benefits. A majority of the respondents reported that by adopting ZBNF, over they saw improvements in yield, soil conservation, seed diversity, quality of produce, household food autonomy, income, and health.

The experience of practicing farmers and field observations over a period of time lends to the following conclusions. Anon (2013) suggests that ZBNF works not just in agronomic terms, but also brings about a variety of social and economic benefits. A majority of respondents reported that by adopting ZBNF, over time they saw improvements in yield, soil conservation, seed diversity, quality produce. Palekar also entitled as "Krishi ka Rishi" by many farmers of Mysore. The preliminary success in Andhra Pradesh is encouraging.

The system of ZBNF is eminently suited to farmers particularly small and marginal farmers because of its simplicity, adoptability and drastically reduction of cost of production. Treatment of Beejamrutha and Jeevamrutha provides adequate protection from pests and diseases during initial stages of germination. In conclusion, Savings on cost of seeds, fertilizers and plant protection chemicals has been considerable. 
Table.1 Basic Pillars of ZBNF

\begin{tabular}{|c|c|c|c|}
\hline $\begin{array}{l}\text { Sr. } \\
\text { No. }\end{array}$ & Methods & Preparration & Benefits \\
\hline 1. & Jivamrita & $\begin{array}{l}\text { It is made from cow-dung ( } 20 \\
\mathrm{~kg}) \text {, urine }(5-10 \mathrm{l}) \text {, jaggery } \\
(20 \mathrm{~kg}) \text { and flour }(2 \mathrm{~kg}) \text { and is } \\
\text { applied to crops with each } \\
\text { irrigation cycle. }\end{array}$ & $\begin{array}{l}\text { It provides nutrients, but it also acts a } \\
\text { catalytic agent which promotes activity } \\
\text { of microorganisms in soil, as well as } \\
\text { increases earthworm activity. It also } \\
\text { helps to prevent from fungal and } \\
\text { bacterial diseases. }\end{array}$ \\
\hline 2. & Bijamrita & $\begin{array}{l}\text { It is basically made up of water } \\
\text { (201), cow dung (5kg), urine } \\
(51) \text {, lime }(50 \mathrm{~g}) \text { and a handful } \\
\text { soil. }\end{array}$ & $\begin{array}{l}\text { It is a seed treatment, equipped in } \\
\text { protecting young roots from fungus as } \\
\text { well as from soil-borne and seed-borne } \\
\text { diseases. }\end{array}$ \\
\hline 3. & $\begin{array}{l}\text { Acchadana- } \\
\text { Mulching }\end{array}$ & $\begin{array}{l}\text { It can be done by soil mulch, } \\
\text { straw mulch. }\end{array}$ & $\begin{array}{l}\text { It conserves soil moisture, by reducing } \\
\text { evaporation. }\end{array}$ \\
\hline 4. & $\begin{array}{l}\text { Whapsa } \\
\text { mositure }\end{array}$ & $\begin{array}{l}\text { The irrigation should be } \\
\text { reduced and irrigation should } \\
\text { be practiced at noon in } \\
\text { alternate furrows. }\end{array}$ & $\begin{array}{l}\text { It is condition where air molecules and } \\
\text { water molecules present in soil. }\end{array}$ \\
\hline
\end{tabular}

Table.2 Pest Management in ZBNF

\begin{tabular}{|c|c|c|c|}
\hline $\begin{array}{c}\text { Sr. } \\
\text { No. }\end{array}$ & $\begin{array}{c}\text { Name of } \\
\text { Pest Mgt. } \\
\text { Formulae }\end{array}$ & Composition & Benefits \\
\hline 1. & Agniastra & $\begin{array}{c}\text { It composed of 101 local cow urine, } 1 \mathrm{~kg} \\
\text { Tobacco, 500gm of Green Chilli, 500gm of } \\
\text { Local Garlic, 5kg Neem leaves pulp (crushed in } \\
\text { urine). For spraying, 21 Brahmastra is taken in } \\
1001 \text { water. }\end{array}$ & $\begin{array}{c}\text { It is effective against } \\
\text { the pests like leaf roller, } \\
\text { stem borer, fruit borer, } \\
\text { pod borer. }\end{array}$ \\
\hline 2. & Brahmastra & $\begin{array}{c}\text { It is prepared by neem leaves, custard apple } \\
\text { leaves, guava leaves, lantern camellia leaves, } \\
\text { pomegranate leaves, papaya leaves and white } \\
\text { dhatura leaves crushed and boiled in urine. }\end{array}$ & $\begin{array}{c}\text { It is used to control all } \\
\text { of sucking pests, fruit } \\
\text { borer, pod borer. }\end{array}$ \\
\hline 3. & Neemastra & $\begin{array}{c}\text { It is made up of local cow urine (5l), cow dung } \\
\text { (5kg) and neem leaves and neem pulp }(5 \mathrm{~kg}) \\
\text { fermented for 24 hrs. }\end{array}$ & $\begin{array}{c}\text { It is used for sucking } \\
\text { pests and mealy bug. }\end{array}$ \\
\hline
\end{tabular}


This system has freed the farmers from the debt trap and instilled in them a renewed sense of confidence to make farming an economically viable speculation. Palekar's Zero Budget Natural Farming has undoubtedly made an stubborn mark on farming in India. More than 40 lakh farmers across the country have benefitted from this type of farming and surely this number will increase tremendously in coming years.

\section{References}

Anonymous, (2016). Venkiah naidu congratulates farmer on winning Padma Shri. Indian Express.

Babu RY, (2008). Action Research Report on Subhash Palekar's "Zero Budget Natural Farming".

GOAP, (2017). Status Note on Zero Budget Natural Farming (ZBNF) in A.P. (mimeo), personal communication.

Jannoura R, Joergensen GR, Bruns C, (2014). Organic fertilizer effects on growth, crop yield, and soil microbial biomass indices in sole and intercropped peas and oats under organic farming conditions. Eur. J Apron. 52(B):259270.

Kumar N, (2012). "Subash Palekar's zero budget no-till rice farming".

La Via Campesina, (2016). Zero Budget Natural Farming in India, www.fao.org/3/a-bl990e.pdf

Palekar

$\mathrm{S}$, (2014). http://www.palekarzerobudgetspiritual farming.org/

Pawar VR, Tambe AD, Patil SP, Suryawanshi SU, (2013). Effect of different organic inputs on yield, economics and microbial count of Sweet Corn (Zea mays Var. Saccharata). Eco. Environ. Conser. 19(3):865-868.

Ramesh P, Rao AS, (2009). Organic farming: Status and Research achievements. Indian Institute of Soil Science Bhopal, 74.

\section{How to cite this article:}

Davinder Pal Singh Badwal, Mandeep Kumar, Harjinder Singh, Simran and Sandeep Kaur. 2019. Zero Budget Natural Farming in India- A Review. Int.J.Curr.Microbiol.App.Sci. 8(12): 869-873. doi: https://doi.org/10.20546/ijcmas.2019.812.111 